\title{
Beyond the Metropolis: French and Belgian Symbolists between the Region and the Republic of Letters
}

\section{DANIEL LAQUA AND CHRISTOPHE VERBRUGGEN}

In 1892 , the editors of the journal La feune Belgique - the bell-ringer of Belgian modernism - made a claim that seemingly contradicted the publication's central role in the country's so-called 'literary renaissance'. I They asserted that their periodical had 'never promoted a national literature, that is to say, "Belgian literature". ${ }^{2}$ Instead, they portrayed themselves as French writers, comparable to authors in Brittany and the South of France:

Nous sommes donc des écrivains français. [...] Les écrivains de souche bretonne, normande ou provençale ont leur accent particulier, nous croyons que les écrivains de Belgique ont aussi le leur. Pourquoi ces derniers, qui sont nés à Bruxelles, à Gand ou à Liège, ne seraient-ils pas des écrivains de langue française au même titre que les écrivains nés à Paimpol, à Rouen ou à Marseille?'

(The writers of Breton, Norman or Provencal origin have their particular accent, and we believe that the writers from Belgium have theirs. Why should the latter, who were born in Brussels, Ghent or Liège, not be French-language authors in the same sense as authors born in Paimpol, Rouen or Marseille?) ${ }^{3}$

Was Belgium merely a region within the French literary world? The debate on whether Francophone Belgian authors represented a national literature rather than being submerged in the wider field of French literature continued in the early twentieth century. Writing during the First World War, the English critic Jethro Bithell acknowledged this controversy, but affirmed the existence of an individual Belgian literature:

There is always the question whether 'Belgian literature' exists at all...[S]ome eminent Belgian writers will not hear of such a thing. And, after all, one never hears of Swiss literature... That may be, however, because there are so few Swiss 
writers of international reputation. Belgium, on the other hand, is not only rich in distinguished writers, but these writers have a marked Belgian individuality. ${ }^{4}$

This individuality, Bithell argued, became evident in the works of Belgian Symbolists: 'There is no distinction to be made between the Belgian Symbolists and the French Symbolists except that the Belgians, true to the doctrine of individualism which is one of the main tenets of the Symbolist school, write poetry which is unmistakably Belgian. The poetry of the Belgian Symbolists is the poetry of Belgian moods.' 5 These different statements draw attention to the complexities of ideas about 'national' literature. Francophone Symbolism in Belgium could be viewed as inherently Belgian, but it could also be represented as part of the French literary field, with shared institutions, publishers, periodicals and critics. ${ }^{6}$ Yet there was a third way in which authors could fashion themselves, namely as members of a 'republic of letters'. Significantly, there was no inherent contradiction between the latter and the potential self-identification as a French author. As Pascale Casanova has argued, Paris was the centre of the 'world republic of letters'; and while Christopher Prendergast has challenged the 'Franco-centric' lens, he still views Paris as a metropolis which constitutes a network of cultural exchanges. ${ }^{7}$

If Belgian literature seems a complex case, similar observations apply to the concept of 'cosmopolitanism'. Steven Vertovec and Robin Cohen have stressed its 'multi-layered character' and the impossibility of reducing it to a 'single conceptualization'. ${ }^{8}$ They therefore offer several 'perspectives on cosmopolitanism' which cover its definition as a 'sociocultural condition' or as a practice, but also encompass political views or projects. ${ }^{9}$ The latter understanding features prominently in the work of scholars such as David Held and Garrett Brown, who use the concept to discuss issues in international politics. ${ }^{\text {IO }}$ Rather than dealing with such 'normative' varieties of cosmopolitanism, this article focuses on forms that can be described as 'cultural cosmopolitanism' and 'cosmopolitanism as a practice'. ${ }^{I I}$ The fin-de-siècle phenomenon that we examine relates to two particular varieties of cosmopolitanism. The first is the openness to transnational exchange and the embrace of diversity. ${ }^{\mathrm{I} 2} \mathrm{We}$ address the international orientation of periodicals, but also draw attention to one specific manifestation of diversity: the roles of French- and Dutchlanguage authors in Belgium, and of Occitan authors in France. The second variety is the recognition of allegedly universal ideals. ${ }^{13}$ For many nineteenth-century commentators, such principles were closely 
associated with French culture. If we interpret Paris as the centre of a cosmopolitan literary network, Belgian authors could affirm their cosmopolitanism through their engagement with French metropolitan literature.

Symbolism provides us with a test case to explore these ambiguities. As a movement, it is notoriously hard to define. ${ }^{\mathrm{I}}$ As early as I899, the British critic Arthur Symons viewed 'self-consciousness' as one of its overarching features. ${ }^{\mathrm{I}}$ Another prominent characteristic was a well-developed periodical culture through which authors could share and disseminate their ideas. ${ }^{16}$ Moreover, it is clear that Symbolism was an international movement with a strong presence in France and Belgium - as reflected in the authors that Symons's book presented to a British audience. Recently, Raphaël Ingelbien has argued that 'there is much more to Symbolism than its supposed internationalism', drawing attention to its regional variants. ${ }^{17}$ This article explores this dimension and stresses many Symbolists' attachment to specific local and regional contexts. It examines the interplay between regional, national and cosmopolitan ideas or practices. To this end, it traces the relationships between Symbolist authors and periodicals from Belgium and southern France where a similar regional phenomenon can be observed. Our essay shows how literary fields emerged in non-metropolitan settings and how literary collaboration integrated them into the wider republic of letters.

\section{DEFINING THE FIELD}

Verbruggen's earlier research has defined the Belgian literary field and its cross-connections to France by mapping the relations between Belgian and French literary periodicals. ${ }^{18}$ The result of his work, a sociogram, covers the relationship between fifteen Belgian and fourteen French literary periodicals for the years I 892 and I 893 (see Figure I). It depicts every Belgian literary journal whose target audience reached beyond an individual city or club, extending to publications that were not part of the Symbolist movement. All of the French journals in this sample were read and reviewed in Belgium, and most of them were associated with Symbolism. The sociogram shows the links between Belgian and French periodicals where at least three authors wrote for each publication. Although it does not correspond with actual geographical locations, it provides a sense of spatiality, with a concentration of periodicals in Brussels (around La Feune Belgique) and Paris (around La Plume and 


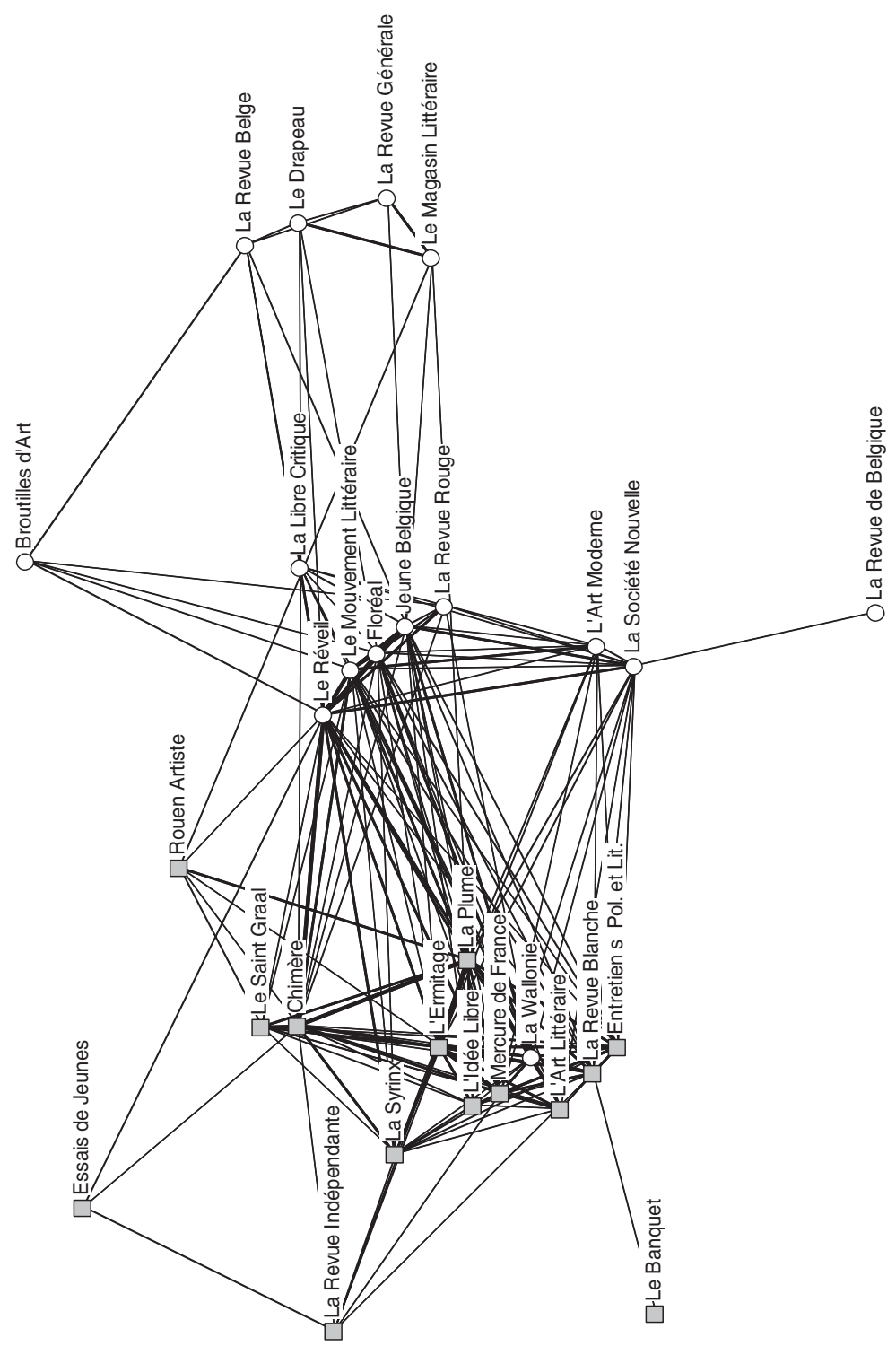

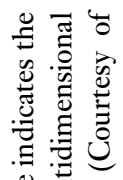

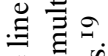

苛

( )

- $\frac{0}{5}$

Е 艺

के

흐웛

过

氧

ఖ

$\exists$ 它

ज एँ

훙

สี ญ्ँ

고음

ป 등

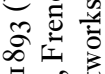

1)

के प्र

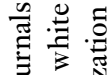

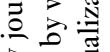

昰总

:

氖

空高

需

.

صै

छ. .

b

㻤苛

纪引

0

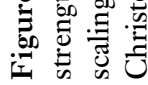


Revue Blanche), but also a number of journals that were published in provincial towns and cities (notably Chimère and Saint Graal). Strikingly, the sociogram only partially reflects Belgium's socio-political divisions. The term 'pillarization' describes the ways in which Belgian society became structured along political-ideological lines, as reflected in the creation of distinct Catholic, liberal and socialist 'pillars' ${ }^{20}$ Such developments could affect literary sociabilities, yet the pluralist nature of several periodicals means that the image does not feature fully isolated Catholic, liberal or socialist journal families.

These findings allow us to draw several conclusions regarding the French and Belgian literary field. For instance, it is evident that three Belgian Symbolist publications-Le Réveil, Floréal and Le Mouvement Littéraire-assumed a central position in literary exchanges, partly reflecting the aesthetic dominance of the Symbolist movement. ${ }^{2 \mathrm{I}}$ Yet other factors could also affect the positioning within the network: $L e$ Réveil had a large number of contributors as it published many short poems; its extensive pool of authors resulted in connections with many other publications. La Wallonie, the iconic Symbolist periodical in Belgium, appears more isolated because it did not maintain links with a cluster of Catholic periodicals in Belgium (Le Magasin Littéraire, La Revue Générale, Le Drapeau). ${ }^{22}$ Instead, this periodical was situated within a cluster of periodicals that were published in Paris: in 1892 , exactly fifty percent of the authors involved in La Wallonie were French and some of the journal's Belgian authors actually lived in Paris. With Henri de Régnier, a disciple of the uncrowned king of Symbolism, Stéphane Mallarmé, La Wallonie even had a Parisian editor.

Despite their considerable ambitions, Le Réveil and Floréal never succeeded in obtaining a similarly pronounced position. The latter was based in the Walloon city of Liège, whereas the former was edited in the Flemish city of Ghent which, alongside its Dutch-speaking majority, also had French-speaking inhabitants. Both periodicals maintained strong ties with a regionalist cluster of journals from the South of France. The identification of this cluster from Occitania - 'le pays de langue d'oc' - is one of the major findings with regard to the French part of this literary field. It comprised four publications: Le Saint Graal (1892-93, successively published in Paris, Chambéry, Aix-les-Bains, Cannes and Puget-Théniers), Chimère (I89I-93, edited in Montpellier), Syrinx (I892-94, edited in Aix-en-Provence) and, to a lesser extent, Essais de Feunes (edited in Toulouse, I892-95) ${ }^{23}$ Meanwhile, the centre of the French field was dominated by four publications that were all 


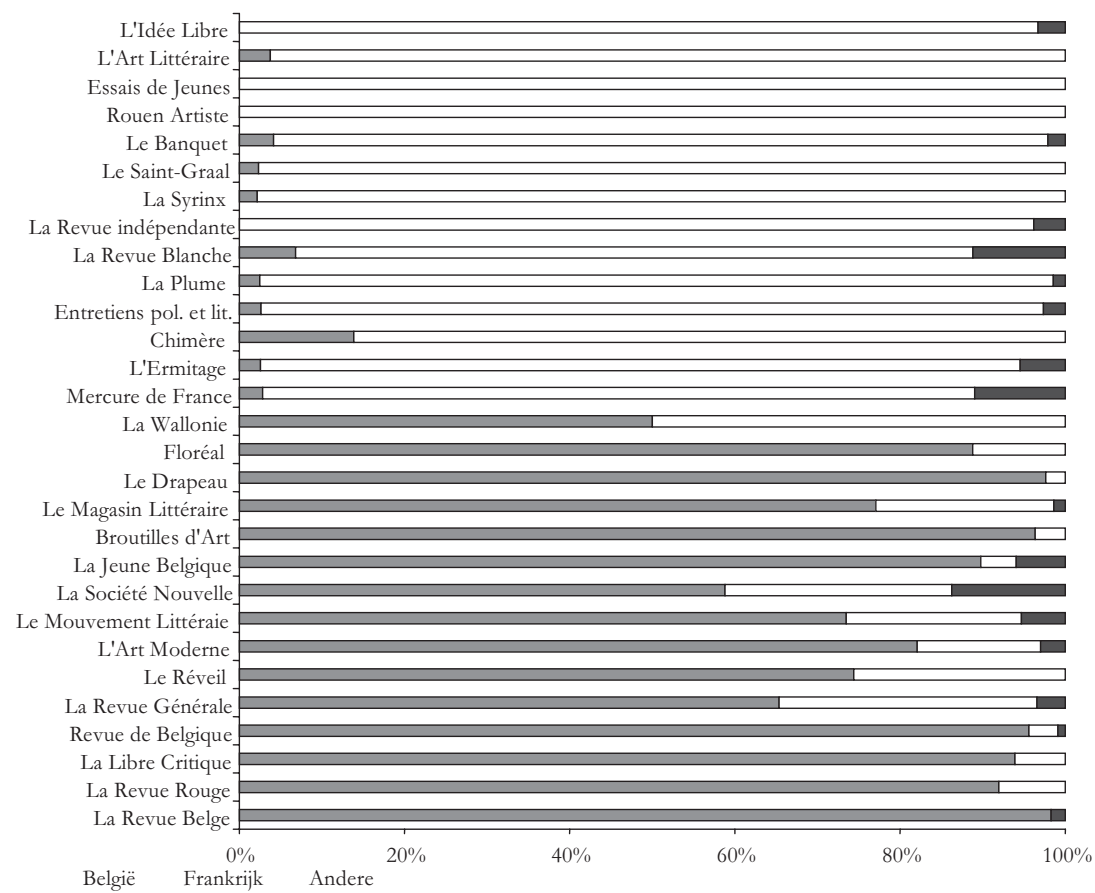

Figure 2. Nationality of the contributors to French and Belgian literary periodicals, I892-93. Belgian: grey. French: white. Other: black. (Courtesy of Christophe Verbruggen.)

edited in Paris and associated with the Symbolist movement: Le Mercure de France, La Revue Blanche, La Plume and L'Ermitage.

\section{AN INTERNATIONAL FIELD AND ITS COSMOPOLITANISM}

While the sociogram clearly suggests that French and Belgian literary periodicals were related to each other via shared authors, it is worth considering the implications for individual periodicals. Figure 2 shows the extent to which journals from both countries published the work of foreign authors. The figures for I 892-1893 suggest that the two Symbolist journals from Paris-Le Mercure de France and La Revue Blanche-had the most international cast of contributors. The foreign connections of the former have also been noted by Robert Jouanny. ${ }^{24}$ As a whole, the number of Belgian contributors to French literary journals may seem relatively low (3.3 per cent; 28 authors), yet Belgians 
nonetheless provided the largest group of foreign authors. Meanwhile, Belgian periodicals contained a significant number of contributions from French authors (I5.9 per cent; I20 French authors). Most Belgian journals sought and attracted a considerable number of foreign authors, with La Revue Belge being an exception to this rule: it explicitly set itself apart from any French influence. In contrast to the prominent FrancoBelgian links, very few German authors published in Symbolist journals. Floréal, edited by the French and German-speaking author and cultural broker Paul Gérardy, did not have a single German collaborator. ${ }^{25}$

As Verbruggen has shown elsewhere, one can distinguish between two different groups of Belgian authors who published in French periodicals. ${ }^{26}$ The first comprised 14 authors below the age of 26 , who edited Belgian periodicals and could thus draw on contacts with France. Their principal connection was with the cluster of periodicals in the South of France, rather than with the Parisian publications. The second group included I4 authors who were older than 26 but still relatively young in literary terms (namely below 38 years of age). This group was linked to Parisian periodicals and included prominent figures such as Emile Verhaeren and Maurice Maeterlinck, recipient of the Nobel Prize for Literature in I9I I. Age-wise, there were two exceptions in this cohort: one was the famous poet and critic Camille Lemonnier, born in I844, whose work covered both Symbolism and Realism. The other was the lawyer, socialist senator and patron of the arts Edmond Picard, born in 1836 . Picard is a controversial figure because of his anti-Semitic writings. ${ }^{27}$ However, as founder of the periodicals La Sociéte Nouvelle, La Revue Moderne and L'Art Moderne, and as supporter of many young artists, he was a key figure in fin-de-siècle Belgium. Despite his antiDreyfusard stance, he has even been described as the nearest equivalent to a 'French-style' intellectual. ${ }^{28}$

The interactions between French and Belgian authors can be interpreted as a cosmopolitan practice in terms of their involvement in a transnational literary field. However, did the actors themselves assess their practices as 'cosmopolitan'? The negative connotations that 'cosmopolitanism' held for many fin-de-siècle observers are well known: 'Un cosmopolite est un dilettante qui voyage' ('A cosmopolitan is a dilettante who travels'), as the Catholic critic Charles Recollin put it. ${ }^{29}$ In the last quarter of the nineteenth century, cosmopolitanism became increasingly juxtaposed with traditional national values-in cultural and political debates, cosmopolitanism was often portrayed as 'antinational'. Yet not every cultural commentator suggested an opposition 
between cosmopolitanism on the one hand, and regionalism, nationalism or patriotism on the other. In 'La Querelle des Nationalistes et des Cosmopolites' ('The quarrel between nationalists and cosmopolitans'), an article published in Le Figaro in I892, Maurice Barrès observed that 'cela est certain, nous allons vers une culture qui sera plus cosmopolite que nationale' ('it is certain that we are moving towards a culture that will be more cosmopolitan than national'). ${ }^{30}$ According to Barrès, even his friend Charles Maurras was not afraid of foreign influences, which would offer spice and flavour to French national culture. Both Barrès (a native from the Vosges) and Maurras (from the South of France) were authors, journalists and activists. During the Dreyfus affair, they represented the anti-Dreyfusard camp and became ardent French nationalists. In I898, Maurras founded the right-wing Action Française, while Barrès became associated with 'Anti-Enlightenment' nationalist and anti-Semitic politics in the French Third Republic. ${ }^{3 \text { I }}$

Given their political trajectory, it is all the more striking that Barrès's Figaro article praised the way in which Picard's left-wing periodical La Société Nouvelle, founded in I884, had fashioned itself as cosmopolitan: 'Il se publie en Belgique un magazine, La Société Nouvelle, de reproductions internationales, en effet, qui est bien le plus intéressant $[\ldots]$ les Belges offensent souvent notre goût, mais ils ont l'intelligence hospitalière. C'est une grande vertu intellectuelle' ('In Belgium, a magazine with international circulation, La Société Nouvelle, is being published which, in fact, is most interesting [...] The Belgians often offend our taste, but they have a hospitable intelligence. This is a great intellectual virtue'). ${ }^{32}$ Barrès's assessment of La Société Nouvelle was certainly correct in that the journal had pronounced cosmopolitan features. ${ }^{33}$ It had, for instance, by far the largest number of foreign contributors. Yet its cosmopolitanism was also reflected in its contents, which included translations of Romantic English authors and writers close to William Morris and the Arts and Crafts movement. Apart from English authors, the publication featured articles on German, Dutch, medieval Flemish, Russian and Scandinavian literature. It also covered contemporary Dutch-language literature produced in Flanders. The journal was simultaneously published in Paris and Brussels and was sold in many cities outside France and Belgium. Such openness to foreign influences and engagement with literary life in other countries did not imply a rejection of national culture. Belgian intellectuals such as the historian Henri Pirenne portrayed their country as a 'microcosm', a 'syncreticism' and an embodiment of the intersection between Latin and 
Germanic civilizations. ${ }^{34}$ In other words, representations of the Belgian nation frequently stressed the country's inherent 'cosmopolitanism'. Thus, the practices of Belgian literary periodicals fed into a discourse about the cosmopolitan qualities of Belgian culture. However, such claims must not be taken at face value. La feune Belgique is a case in point. As figure 2 has shown, it featured various contributors from abroad. It also covered international literary developments, for instance discussing Russian naturalism. ${ }^{35}$ Nonetheless, it was also a forum in which - in reference to Walt Whitman - the poet Iwan Gilkin deplored the 'invasion of the barbarians'.$^{6}$ His focus was not Belgian literature; as a Francophone author, he was concerned with the Graeco-Latin roots of French literature. Meanwhile, other contributors to the periodical expressed their concern about German influences. ${ }^{37}$ Such dimensions stress that potential cosmopolitan outlooks or practices stood in constant tension with apprehensions regarding cultural integrity.

\section{BETWEEN COSMOPOLITANISM AND REGIONALISM}

Both in the Belgian and the French case, cosmopolitanism did not only maintain an ambivalent relationship with concepts of nationhood: it went hand in hand with regionalism. Indeed, it has been argued that regionalism - rather than being a peripheral variant of Symbolism - was at the very heart of the movement. ${ }^{38}$ In the Belgian case, this was particularly evident in the representation of the Flemish region. Whilst publishing in French, authors such as Emile Verhaeren, Maurice Maeterlinck and Georges Rodenbach celebrated Flanders, whose population was overwhelmingly Dutch-speaking. Francophone Belgian Symbolists used Flemish characters, history and the topography in their poetry. The terroir was both a source of inspiration and part of the Symbolist aesthetics.

Even though Belgium's literary revival was initially associated with Francophone authors, in the early I89os, a small group of Dutchspeaking Flemish writers took their cue both from the Francophone pioneers and from writers in the Netherlands around the journal $D e$ Nieume Gids ('The New Guide', I 885-1943). These Flemish intellectuals launched their own periodical, Van Nu en Straks ('Of Now and Later', I893-1901), in which they sought to reconcile the concept of the autonomy of literature with the edification and education of the people. In doing so, they could build on existing associations and cultural links. ${ }^{39}$ While the overall response to this initiative was favourable, there was 
little exchange - as represented by translated articles or poems - between French- and Dutch-language journals. The leading theorist of $\mathrm{Van} N u$ en Straks was August Vermeylen, who published his influential 'Kritiek der Vlaamsche beweging' ('Critique of the Flemish Movement') in I $895 .^{4^{\circ}}$ In this essay, he argued that international modernism should be integrated into new national expressions in which the Flemish region and language were to take centre stage. In doing so, Vermeylen fostered an image of Flanders that placed it at the heart of European cultural life, an argument which he developed further in his essay 'Vlaamsche en Europeesche beweging', published in r9o г.$^{4 \mathrm{I}}$ Nele Bemong, Raphaël Ingelbien and others have interpreted these developments as a shift to 'literary nationalism' in the late nineteenth century, partly triggered by intellectuals who sought both to distinguish themselves from their Romantic predecessors and to establish themselves as part of an international literary field. ${ }^{42}$

The celebration of the region among both French- and Dutchspeaking Belgian authors was mirrored by the separate literary cluster that we have identified in the South of France. Several editors of these periodicals were active in the Occitan revival movement known as the 'Félibrige'. Le Saint Graal, and to a lesser extent, Chimère combined regionalism with Catholic mysticism and occult Symbolism. ${ }^{43}$ By focusing on their origins in their writings and defining themselves as a group, authors from Provence represented themselves in and vis-à-vis Paris. ${ }^{44}$ Chimere, published in Montpellier, had been founded and edited by Paul Redonnel, a former classmate of Jean Charles-Brun. 45 CharlesBrun was a Catholic Dreyfusard who in 1900 founded the Fédération Régionaliste Française in opposition to the Action Française. In the early i 89os, however, Redonnel, Charles-Brun and Charles Maurras still collaborated in and around the (mostly Paris-based) Félibrige movement. As the secretary of La Plume, Redonnel positioned himself at the core of the Symbolist movement. ${ }^{4}$ In those years he also befriended the young André Gide, who eventually published a few poems in Chimère under the pseudonym of André Walter. ${ }^{47}$ Redonnel left Paris in I 892 and settled in Montpellier to devote himself fully to occultism and regionalism by editing a journal. He asked Léon Durocher from Brittany to act as his assistant. The latter was unable to combine his editorial duties with his engagement in the travelling cabaret Le Chat Noir (which also performed in Belgium the same year). Durocher was replaced by two other 'disciples of Félibrige', Joseph Loubet and Pierre Devoluy..$^{8}$ When he was asked about the mission statement of Chimère, Redonnel described it as 'eclectic': 
Nous essayâmes de prouver que l'art moderne et le catholicisme ne sont conciliables, que le patriotisme est beau en dehors de toute intellectualité; et sans trop approfondir, comme il seyait, nous formulâmes notre socialisme, notre positivisme et notre idéalisme, nullement incompatible entre eux [...] On sait que la Revue naquit à Montpellier, ville de réputation très haute, à cause de son université; et par l'organe de quelques jeunes d'élite, nous suscita, en secondant, une tentative décentralisatrice

(We tried to prove that modern art and Catholicism can be combined, that patriotism is beautiful without any intellectualism, [...] we formulated our socialism, our positivism and our idealism, none of them incompatible with each other [...] People know that the review was born in Montpellier, a city of very high reputation because of its university; and through the publication of a young elite, a decentralizing attempt emerged. $)^{49}$

Chimère sought bonds with Paris, fitting in with the idea of 'literary federalism' - a notion coined by the Félibrige movement's founding father, Fredéric Mistral. The mother tongue (Occitan) would sit side by side with the national language (French). ${ }^{50}$ Such a view was echoed by Barrès, to whom it seemed obvious that national identities were composed of 'nationalités provinciales'.$^{5}$ The discussion of literary federalism in Chimère was a direct reaction against the growing 'integrism' of Charles Maurras, who developed an ambivalent relationship with the 'Nordic' (and non-French) Maeterlinck. In Maurras's view, Nordic influences could not be an integral part of the French nation and the country's political organization, contrary to the Catholic religion, French language and traditions. The underlying rifts - which were thus not only of a cultural but also an ideological nature-had become evident with the foundation of the École Romane in $1891 . .^{2}$ The École was a group of young poets (including Maurras and Jean Moréas) who reacted to the dominance of Symbolism by promoting a return to classicism, without breaking completely with their Symbolist peers. However, inevitably a request for literary federalism - that is to say the coexistence of provincial languages with an official language - would always coincide with political requests, as one observer commented on the 'félibrige littéraire' and the 'félibrige social' (i.e. political) in I9 Io. ${ }^{53}$ This point invites comparison with the role of the Flemish region and language in Vermeylen's work: the Flemish author's focus was not a political statement against the Belgian state-even though it was later used and read as an expression of Flemish political nationalism. ${ }^{54}$

The Occitan and Belgian periodicals did not merely share an attachment to their respective regions. As Figure I demonstrates, there 
were clear links between the Occitan and the Flemish clusters. The strongest relation between a French and a Belgian periodical was the one between Chimère and the Ghent-based Le Réveil, both of which placed the region at the core of their aesthetics. The two publications shared 24 authors, which is a stronger relation than Le Réveil had with any other journal. Le Réveil was not the only Belgian journal to maintain close relations with Chimère. Les feunes (I890-9I) was founded by students and a publisher in Namur, a provincial administrative town. Again, the periodical was characterized by an attachment to a particular region - in this case Wallonia. Supporters of the Walloon dialect, for instance the 'fumiste wallon' Charles Frappart and the journalist Auguste Vierset, published in it, alongside various occultist writers. Due to its short-lived nature, we know little about the founders and protagonists of Les Feunes. We do know that Geo Mauvère, alias Georges Angelroth, represented the journal at literary events in Brussels, where he studied. ${ }^{55}$ After only two years of existence, Les Feunes announced its merger with Chimere..$^{6}$ Mauvère collected the contributions of Belgian authors and sent them to Chimère's offices in Montpellier. The collaboration between the French and the Belgian periodicals was enabled by personal friendships and shared experiences: students involved in Chimère and Les feunes took part in exchange programmes and international conferences of student societies in Brussels, Ghent, Montpellier and Paris. ${ }^{57}$

Not everyone agreed with the intense contacts between Belgian authors and their peers from the South of France. Maurras asked for 'la horde des belges' ('the hordes of Belgians') to be stopped, in order to preserve the Latin spirit of France-a stance about which the editors of Chimère's Belgian sister journal, Le Réveil, expressed their deep regret. For the young Francophone poets from Ghent there were no borders between poetry in the French-speaking world..$^{8}$ Their reaction towards Maurras shows that long before Catholic writers and critics such as Henri Davignon and Pierre Nothomb fully embraced the ideas propagated by the Action Française, Maurras was well-known in Belgian intellectual circles. ${ }^{59}$ Probably due to financial problems, Chimère ceased publication in I 894. However, this did not mark the end of the intense collaboration between French and Belgian authors. Its successor La Coupe, also published in Montpellier, renewed the interest in a Belgian Symbolism that was rooted in Flemish clay. ${ }^{60}$ The journal solicited contributions from Maeterlinck, Verhaeren, Rodenbach and Van Lerberghe on various occasions. 
The case of Belgian Symbolism had cosmopolitan features in several respects. If we view 'cosmopolitanism' as a manifestation of universal principles which many contemporaries associated with Parisian culture, Symbolism was certainly cosmopolitan. Belgian authors and periodicals maintained close links with their French counterparts and thus involved themselves in the 'republic of letters'. At a different level, however, the regionalism of periodicals in Flanders, Wallonia and the South of France furthered another form of cosmopolitanism: the celebration of cultural diversity. In this respect, the case of the Occitan and Flemish Symbolists refers back to longer-standing traditions: David Damrosch has suggested that 'global' or 'cosmopolitan' regionalism was characterized by a dialogue between different and yet interrelated literary identities: local, national and international. ${ }^{6 \mathrm{I}}$ In many respects, the practices and attitudes that have been discussed here were 'micro-cosmopolitan', as defined by Michael Cronin: they did 'not involve the opposition of smaller political units to larger political units (national, transnational)'. Instead, a broader cosmopolitan context helped to 'diversify or complexify the smaller unit'. ${ }^{62}$

French-speaking Belgian authors adopted a double strategy: their purpose was to enlarge and protect their market by playing both the national and the Parisian card. ${ }^{63}$ Such a duality can lead to the somewhat paradoxical situation that, with growing success, authors might be perceived as 'French' rather than 'Belgian'. Dutch-speaking authors followed similar aims vis-à-vis the Netherlands. ${ }^{64}$ It is worthwhile returning to Casanova's work, as she has acknowledged the 'International of Small Nations', stressing that 'small nations-or rather the international writers of small literatures - could act in concert to challenge their domination'. ${ }^{6}$ In this context, she places particular emphasis on the way in which Belgium provided an example for authors from other small nations, including Ireland and Norway. Thus, literatures from peripheral countries were characterized by a sustained effort to construct a distinct national literary identity and by the ambition to represent themselves internationally. In this respect, cosmopolitan practices could also perform a national role.

Ingelbien's comparative approach to Symbolism has revealed similarities between Maurice Maeterlinck and W. B. Yeats, who both operated from the periphery of modernist internationalism and Symbolism. Both authors defined themselves in opposition to metropolitan culture 
(associated with cosmopolitanism) and fell back upon folklore. This comparison has allowed Ingelbien to propose a new typology of European Symbolism, including a 'peripheral Symbolism that was articulated round the social, cultural and linguistic tensions affecting two relatively marginal nations'. ${ }^{66}$ We can support this typology by adding domestic French tensions between province and metropolis. Our network approach has revealed strong transnational connections between authors and journals in Belgium and the South of France. This should not obscure the differences between the two cases: prior to the First World War, literary regionalism was not perceived as dangerous for the unity of the Belgian state. On the contrary, the integration of Flemish and Walloon regionalisms was perceived as an integral part of Belgium's cosmopolitan master narrative. From this perspective we can discern continuities from the Romantic era. French regionalism, however, was suspected much sooner of undermining the unitary republican state. The appeal for literary federalism in France soon coincided with social and political demands and an ambition to reform or transform the Third Republic.

\section{NOTES}

I This 'renaissance' was characterized by the emancipation from Romantic models and the creation of new vehicles for literary debate. La feune Belgique was a particularly prominent example of these developments. Contrary to its later opponent L'Art Moderne, a proponent of 'social art', it favoured socio-political autonomy and a pure aestheticism.

2 'La Jeune Belgique n'a jamais préconisé une littérature nationale, c'est-à-dire une littérature belge.' 'Questions du jour', La feune Belgique, I I (I892), 362-363.

3 'Questions du jour', pp. 362-363.

4 Jethro Bithell, Contemporary Belgian Literature (London: T. Fisher Unwin, I9I5), pp. viii-ix.

5 Bithell, Contemporary Belgian Literature, p. I9o.

6 See, for example: Pierre Bourdieu, 'Existe-t-il une littérature belge? Limites d'un champ et frontières politiques', Etudes de Lettres. Revue de la Faculté des lettres de l'université de Lausanne, 3 (I985), 3-6; Pierre Bourdieu, 'Champs littéraire et rapports de domination: Un entretien de Jacques Dubois avec Pierre Bourdieu', Textyles, I 5 (1998), I2-I6; Benoît Denis and Jean-Marie Klinkenberg, La Littérature belge: Précis d'histoire sociale (Brussels: Labor, 2005); Joseph Jurt, 'Le champ littéraire entre le national et le transnational', in L'espace intellectuel en Europe: De la formation des États-nations à la mondialisation XIXe-XXIe siècle, edited by Gisèle Sapiro (Paris: La Découverte, 2009), pp. 20 I-232.

7 Pascale Casanova, La République mondiale des lettres (Paris: Seuil, I999), translated into English by M. B. DeBevoise as The World Republic of Letters (Cambridge, MA: 
Harvard University Press, 2007); Christopher Prendergast, 'The World Republic of Letters', in Debating World Literature, edited by Christopher Prendergast (London: Verso, 2004), p. I-24. Cf. Michael Boyden, 'Why the World Is Never Enough: Re-Conceptualizing World Literature as a Self-Substitutive Order', in Re-Thinking Europe: Literature and (Trans) National Identity, edited by Nele Bemong, Mirjam Truwant and Pieter Vermeulen (Amsterdam: Rodopi, 2008), pp. 59-79.

8 Steven Vertovec and Robin Cohen, 'Introduction: Conceiving Cosmopolitanism', in Conceiving Cosmopolitanism: Theory, Context, and Practice, edited by Vertovec and Cohen (Oxford: Oxford University Press, 2002), pp. I-24 (p. 5).

9 Vertovec and Cohen, 'Introduction: Conceiving Cosmopolitanism', pp. 9-I 5.

Io Their edited volume includes Kantian perspectives, discussions of 'Cosmopolitan Global Justice' and issues in the field of global governance. See Garrett Wallace Brown and David Held, The Cosmopolitanism Reader (Cambridge: Polity, 2010).

I I The Ashgate Research Companion to Cosmopolitanism, edited by Maria Rovisco and Magdalena Nowicka (Farnham: Ashgate, 20 I I).

I2 In his discussion of a globalized world, Beck promotes a 'cosmopolitan vision' that acknowledges diversity and cultural exchange; Ulrich Beck, Der kosmopolitische Blick oder: Krieg ist Frieden (Frankfurt a.M.: Suhrkamp, 2004).

I3 So Yang Park, 'Cosmopolitanism and Universalism', in Dictionary of Transnational History, edited by Akira Iriye and Pierre-Yves Saunier (Basingstoke: Palgrave 2009), pp. 219-220.

I4 For an overview, see Henri Dorra, Symbolist Art Theories: A Critical Anthology (Berkeley, CA: University of California Press, 1994).

I5 Arthur Symons, The Symbolist Movement in Literature (I899) (New York: E. P. Dutton, I919).

I6 Paul Aron, 'Les revues littéraires: histoire et problématique', COnTEXTES 4 (2008); online version < http://contextes.revues.org/38I3 > [accessed 28 May 2012]; Pierre Yves Soucy and Paul Aron, Les Revues littéraires belges de langue française de I 830 à nos jours: Essai de répertoire (Brussels: Labor, I993); Joseph Jurt, 'Les mécanismes de constitution de groupes littéraires: L'exemple du Symbolisme', Neophilologus, 70 (1986), 20-33.

I7 Raphael Ingelbien, 'Symbolism at the Periphery: Yeats, Maeterlinck and Cultural Nationalism', Comparative Literature Studies, 42 (2005), I83-204 (p. 201 ).

I8 Christophe Verbruggen, 'Combining Social Network Analysis and Prosopography', in Guide to the Principles and Practice of Prosopography, edited by Katherine S. B. Keats-Rohan (Oxford: Unit for Prosopographical Research, 2007), pp. 579-599; Christophe Verbruggen, Schrijverschap in de Belgische belle époque: Een socialculturele geschiedenis (Ghent: Academia Press, 2009), pp. I92-232. See also Franco Moretti, 'Conjectures on World Literature', in Debating World Literature, edited by Prendergast, pp. I48-I62.

I9 For other graphic techniques and the precise explanation of MDS, see Linton C. Freeman, 'Graphic techniques for exploring social network data', in Models and Methods in Social Network Analysis, edited by P. J. Carrington and others (Cambridge: Cambridge University Press, 2005), pp. 248-269.

20 Staf Hellemans, Strijd om de moderniteit: sociale bemegingen en verzuiling in Europa sinds I 800 (Leuven: Universitaire Pers Leuven, I990). 
2 I For a survey of Symbolism in Belgium, see Herman Braet, L'Accueil fait au Symbolisme en Belgique (I885-I900): contribution à l'étude du mouvement et de la critique Symbolistes (Brussels: Palais des Académies, I967).

22 On this periodical, which ceased publication in the winter of 1892 , see Andrew Mathews, La Wallonie (I886-I892): The Symbolist Movement in Belgium (New York: King's Crown Press, I947).

23 Julian Wright, The Regionalist Movement in France, I890-19I4: Jean Charles-Brun and French Political Thought (Oxford: Oxford University Press, 2003), pp. 56-57.

24 Robert Jouanny, 'Les orientations étrangères au "Mercure de France" (I 890-I 895)', Revue d'Histoire Littéraire de la France, 92 (1992), 6-72. On the La Revue Blanche, see A. B. Jackson, La Revue blanche I889-I903: Origine, Influence, Bibliographie (Paris: Minard, I960).

25 Marcel Gsteiger, 'Paul Gérardy, poète Symboliste entre deux littératures', in Autour de Paul Gérardy médiateurs et médiations littéraires et artistiques à l'époque du Symbolisme entre l'Allemagne, la Belgique et la France, edited by Jean-Marie d'Heur and Armand Nivelle (Liege: n. pub, I984), pp. 55-63.

26 Verbruggen, 'Combining Social Network Analysis and Prosopography', pp. 594-599.

27 Foulek Ringelheim, Edmond Picard: jurisconsulte de Race (Brussels: Larcier, 1999).

28 Marc Quaghebeur and Madéleine Rebérioux, 'Intellectuels en Belgique et en France. "Pilliers" citoyenneté, Etat', Le Mouvement Social, I78 (I997), I I0-I I2.

29 Charles Recollin, L'Anarchie Littéraire (Paris: Perrin, I898), p. 27. Cited in Nicolas Di Méo, Le cosmopolitisme dans la littérature française: De Paul Bourget à Marguerite Yourcenar (Geneva: Droz, 2009), p. $35^{2}$.

30 Maurice Barrès, 'La Querelle des Nationalistes et des Cosmopolites', Le Figaro, 4 July I 892 , p. I.

3I See David Carroll, French Literary Fascism: Nationalism, Anti-Semitism and the Ideology of Culture (Princeton: Princeton University Press, 1995); Zeev Sternhell, The Anti-Enlightenment Tradition (Yale: Yale University Press, 2009); Michael Sutton, Nationalism, Positivism and Catholicism: The Politics of Charles Maurras (Cambridge: Cambridge University Press, 1982).

32 Barrès, 'La Querelle des Nationalistes et des Cosmopolites'.

33 Paul Aron, 'La Belgique Francophone, carrefour du cosmopolitisme européen', in La Belle Epoque des revues, I880-I9I4, edited by Jacqueline Pluet-Despatin, Michel Leymarie, and Jean-Yves Mollier (Paris: Labor, 2002), pp. 325-334; Paul Delsemme, 'La Société Nouvelle, Revue Internationale (ie Série, I884-I897)', in Autour de Paul Gérardy, pp. гог-2го; Fabrice Wilvers, "La Société Nouvelle” et "L'Humanité Nouvelle", deux revues cosmopolites et pluralistes' (unpublished Phd thesis, Brussels, 2002).

34 Jo Tollebeek, 'Het koppelteken van de nationale cultuur: de Paradox van de eigenheid in België en Nederland, I860-1918', in Naties in een spanningsveld: tegenstrijdige bemegingen in de identiteitsvorming in negentiende-eeums Vlaanderen en Nederland, edited by Nele Bemong and others (Hilversum: Verloren, 20 Io), pp. I 5-32. See also Daniel Laqua, The Age of Internationalism and Belgium, I880-1930: Peace, Progress and Prestige (Manchester: Manchester University Press, 2013), pp. I9-2 I.

35 The periodical's reception of Russian literature is discussed in Raymond Trousson, 'La Jeune Belgique et les lettres belges', in Lettres ou ne pas Lettres: mélanges de littérature française de Belgique offerts à Roland Beyen, edited by Jan Herman, 
Lieven Tack and Koenrad Geldof (Leuven: Leuven University Press, 200I), pp. $55^{-56}$.

36 Laurence Brogniet, 'Le mythe de l'invasion des barbares en Belgique: art et/ou révolution au tournant du siècle', in Mythes de la décadence, edited by Alain Montandon (Clermont-Ferrand: Presses Universitaires Blaise Pascal, 200I), pp. I $57-158$. The essay in question is Iwan Gilkin, 'L'invasion des barbares', $\mathrm{La}$ Feune Belgique (August I 892).

37 Trousson, 'La Jeune Belgique et les lettres Belges', p. 555.

38 Michel Décaudin, La crise des valeurs Symbolistes: vingt ans de poésie française (1895-I9I4) (Toulouse: Privat, I960), pp. 34-38.

39 Raymond Vervliet, De literaire manifesten van het fin de siècle in de Zuidnederlandse periodieken I878-I9I4 (Ghent: Rijksuniversiteit, I982); Greet Draye, Laboratoria van de natie: literaire genootschappen in Vlaanderen I830-I9I4 (Nijmegen: Vantilt, 2009).

40 Auguste Vermeylen, 'Kritiek der Vlaamsche beweging', Van Nu en Straks, I (I896), I-34. See Hans Vandevoorde, 'Inleiding. Eenheid en verscheidenheid in Van $\mathrm{Nu}$ en Straks', in Niet onder één vlag. Van Nu en Straks en de paradoxen van het fin de siècle, edited by Hans Vandevoorde, Geraldine Reymenants and Raf De Bont (Gent: KANTL, 2005), pp. I-24.

4I Auguste Vermeylen, 'Vlaamsche en Europeesche beweging', $\mathrm{Van} N u$ en Straks, 4 (I900), 299-3 Io. See Matthijs De Ridder, 'Europeanism in One Country: August Vermeylen, Paul Van Ostaijen and the Internationalist Approach to Nationalism', in Re-Thinking Europe, pp. 2 I-32.

42 Nele Bemong, Mary Kemperink, Marita Mathijsen and others, 'Het spanningsveld van het nationale denken', in Naties in een spanningsveld, pp. 7-I3.

43 For Le Saint Graal, see Jean-Michel Place, 'Le Saint-Graal', in Bibliographie des revues et journaux littéraires des XIXe et XXe siècles, edited by Jean-Michel Place and André Vasseur (Paris: Editions de la chronique des lettres françaises, I973), pp. 272-289.

44 Décaudin, La crise des valeurs Symbolistes, pp. 34-38. This strategy is described by Bourdieu in 'Existe-t-il une littérature belge?' as essential for the Belgian authors who were not successful in Paris.

45 Wright, The Regionalist Movement in France, p. 55.

46 For Redonnel, see Guy Barral, 'Paul Redonnel (I860-I935): un ouvreur des littératures françaises et occitanes : Splendeur des revues Symbolistes à Paris et à Montpellier', < http://bibliophilelanguedocien.blogspot.com/2012/02/paulredonnel-I 860-I 935-un-ouvreur-des.html $>$ [accessed 28 May 20I2].

47 See Robert Mallet, André Gide et Paul Valéry: Correspondance (I890-1942) (Paris: Gallimard, 1955), p. 71. Cf. Gide's hybrid work Les Cahiers et les Poésies d'André Walter, originally published in two separate parts in I $89 \mathrm{I}$ and $\mathrm{I} 892$.

48 Loubet was also a close friend of Jean Charles-Brun. See Wright, The Regionalist Movement in France, p. 47.

49 Paul Redonnel, 'Chimère', Le Mouvement Littéraire, 2 (I 893), 205-206.

50 'En quelques mots nous serons fédéralistes littéraires; de cœur et d'âme avec nous [...] faire marcher côte à côte la langue maternelle et la lange nationale.' Redonnel, 'Chimère', 205-206. 
5I G. D'Azambuja, 'A travers les revues: M. Barrès et le Fédéralisme', Le Mouvement Social, 5 ( 1 896), I4-I7.

52 Richard Shryock, 'Reaction Within Symbolism: The École Romane', The French Reviem, 7 I (I998), 577-584.

53 '[C]'est-à-dire la coexistence des langues provinciales et d'une langue officielle, devaient nécessairement être amenés à admettre la coexistence de nationalités provinciales jouissant d'une certaine autonomie et d'un organisme central dont le pouvoir s'exercerait uniquement sur les questions d'ordre général.' 'Chronique du Midi', Mercure de France, I6 November i910, 362-367. Cf. Yvan Gaussen, Du fédéralisme de Proudhon au Félibrige de Mistral (Paris: Chastanier, 1927).

54 Raphaël Ingelbien, 'De "paradox" van het fin-de-siècle literair internationalisme', in Naties in een spanningsveld, pp. 33-48.

55 For instance at the banquet; to celebrate the anniversary of La feune Belgique; 'Banquet du Xe anniversaire de la Jeune Belgique', La feune Belgique, Io (I89r), 98.

56 Louis D. B., 'A travers les revues', Essais publiés par le Cercle littéraire français, I I (I89I), I6o.

57 This description is very prominent in the memoirs of André Fontainas, one of the protagonists in the formation of networks between Belgium and France at the end of the nineteenth century. See André Fontainas, Mes souvenirs du Symbolisme (Brussels: Labor, I99I).

58 'A travers des Revues', Le Réveil, 3 (1893), 94.

59 For the reception of Maurras in Belgium, see Olivier Dard, 'Etat des lieux et perspectives autour du maurassisme hors de France', in Charles Maurras et l'etranger - L'étranger et Charles Maurras, edited by Oliver Dard and Michel Grunewald (Berne: Peter Lang, 2009), pp. 29-58; Eric Defoort, Charles Maurras en de Action française in België (Nijmegen and Bruges: Gottmer-Orion, I978).

6o La Coupe was edited by Joseph Loubet, another member of the Félibrige. J. Lesaffre, 'La Coupe', in Bibliographie des revues et journaux littéraires, pp. 333-343.

6I David Damrosch, 'Global Regionalism', European Reviem, I 5 (2007), I35-4I3.

62 Michael Cronin, Translation and Identity (Abingdon: Routledge, 2006), p. I5.

63 Michel Biron, La modernité belge: Littérature et société (Brussels: Labor, 1994), p. 53.

64 Hans Vandevoorde and Christophe Verbruggen, 'The Professionalisation of the Author in Belgium Around I90o', in Authorship Revisited: Conceptions of Authorship around 1900 and 2000 , edited by Gillis J. Dorleijn, Ralf Grüttemeier and Liesbeth Korthals Altes (Leuven: Peeters, 2010), pp. 39-5I.

65 Casanova, World Republic of Letters, pp. 247-248.

66 Ingelbien, 'Symbolism at the Periphery', p. I99. 